\title{
INCOME INEQUALITY AROUND THE WORLD
}

\author{
Gulzar TAHIROVA ${ }^{1}$ \\ Ramiz RAHMANOV ${ }^{2}$ \\ Asif QASIMOV $^{3}$
}

\begin{tabular}{ll}
\hline JEL I24, K40, O15 & \begin{tabular}{l} 
Abstract \\
\cline { 2 - 2 }
\end{tabular} \\
$\begin{array}{l}\text { This paper aims to identify the significant determinants of income } \\
\text { inequality in developed and developing countries. The empirical } \\
\text { analysis of the panel of } 147 \text { countries over the period from } 1980 \text { to }\end{array}$ \\
$\begin{array}{l}2010 \text { shows that for developed countries, the significant determinant } \\
\text { of income inequality is public spending on education, and for } \\
\text { Keywords: } \\
\text { Inequality, } \\
\text { education, income, } \\
\text { finance, institutions, } \\
\text { infrastructure. }\end{array}$ & $\begin{array}{l}\text { development. Furthermore, no significant evidence supporting the } \\
\text { existence of Kuznets' curve is found. }\end{array}$
\end{tabular}

\section{Introduction}

Income inequality has always been an important issue for economic, social, and political reasons. In countries with high income inequality, households at the bottom of the income distribution face difficulties in maintaining their consumption and financing their debt in the short-run. Such circumstances lead to a decline in aggregate consumption and increase the proportion of non-performing loans, thereby worsening the economic performance of the country and increasing the fragility of the financial sector. High income inequality also creates social challenges since households at the bottom cannot access good quality health care and education services because of unfavorable affordability. As a result, the society has a stratum of socially excluded households which can threaten social stability as well as economic development of the country. Finally, unequal societies tend to have political systems which serve interests of the rich. The poor households can blame the biased politicians in their misfortune and express their dissenting opinion by creating social unrest.

${ }^{1}$ Economic Development Research Department, Central Bank of the Republic of Azerbaijan, Baku, Azerbaijan. e-mail: gulzar_tahirova@cbar.az

2 Economic Development Research Department, Central Bank of the Republic of Azerbaijan, Baku, Azerbaijan.e-mail: ramiz_rahmanov@cbar.az

3 Economic Development Research Department, Central Bank of the Republic of Azerbaijan, Baku, Azerbaijan.e-mail: asif_qasimov@cbar.az 
Finding the significant determinants of income inequality is necessary in order to design policies which will be able to reduce inequality and thereby prevent its negative consequences. This paper attempts to identify significant determinants of income inequality for developed and developing countries. The estimation results show that in developed countries, the only statistically significant determinant is public spending on education. In developing countries, the significant determinants include public spending on education, affordability of credits, and infrastructural development. The income level and maturity of the legal system have no significant influence on income inequality in both developing and developed countries. Furthermore, we fail to find any significant evidence in favor of the existence of Kuznets' curve.

There exists a large body of literature on determinants of income inequality, most of which focuses on one or two determinants. This paper extends the existing literature by analyzing a rich set of determinants of income inequality and a large sample of developed and developing countries at the same time. Such a fortunate combination will allow us to obtain more accurate, up-to-date and efficient estimates and thereby provide solid empirical evidence for designing effective anti-inequality policies.

The rest of the paper is organized as follows. The next section analyzes the evolution of income inequality in developed and developing countries. In the following section, we provide an overview of the potential determinants of income inequality. The fourth section specifies the equations, the fifth section describes the data, and the sixth section presents and discusses the results. The final section concludes the paper with the summary of the empirical results and their policy implications.

\section{Evolution of income inequality}

In the mid 1980s, the world average of the Gini coefficient was at the level of 34.89 (Figure 1). By the mid 1990s, the average value of the coefficient increased by $14 \%$. Then the equality began improving but the world in 2010 was still more unequal than it was 25 years ago. 


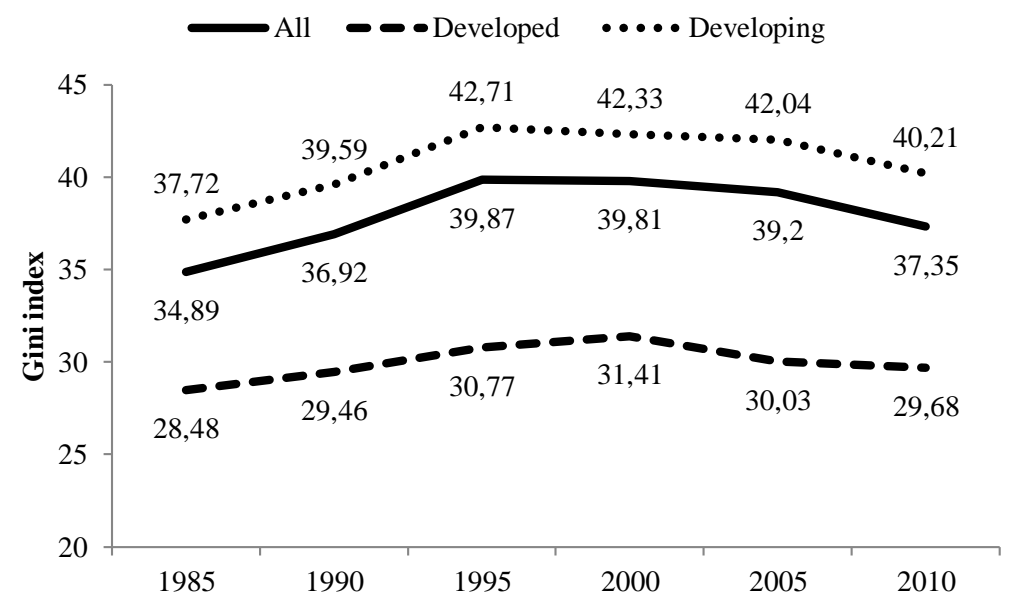

Sources: World Bank, OECD, European Commission, UN WIDER, and the Gini project.

\section{Figure 1. Income inequality around the world ${ }^{1}$}

If we split our sample into developing and developed countries, we observe that the level of inequality in developing countries has been always higher than that in developed countries (Figure 1). For example, in the mid 1980s, the value of the Gini index in developing countries was $32 \%$ greater than the value of the index in developed countries. It is also interesting that the gap between inequality levels of the poor and rich countries did not decline but slightly increased. Thus, in 2010, the Gini index in developing countries became $35 \%$ higher than in developed countries.

Furthermore, over time the evolution of inequality in developed and developing countries demonstrated different patterns. In developing countries, the inequality was increasing from the mid 1980s till the mid 1990s, and then it started gradually declining. In developed countries, the Gini index was increasing for a longer period, till 2000, and then it was decreasing till 2010. The common feature for both developed and developing countries is that in 2010, the societies in both country groups became more unequal than they were in 1985 .

\section{Determinants of income inequality}

Evolution of income inequality is not an ad-hoc process but the consequence of changes in the economic and social environment. The elements of this environment include income level, financial development, availability and quality of education, 
infrastructural development, and maturity of institutions. Below we will separately discuss the mechanics of each element.

\section{Income level}

An increase in income level is supposed to reduce income inequality because economic development assumes an increase in the state budget income which, in turn, allows the government to finance generous social assistance programs. However, in the seminal paper, Kuznets (1955) concludes that at the early stages of economic development, income inequality increases, then it stabilizes, and, at the later stages, it declines. Graphically, the relationship between income and inequality has an inverted U shape. According to Kuznets (1955), at the first stages of economic development, assets and therefore income generated by the assets are concentrated in hands of the small fraction of population. At the same time, as the industrialization progresses, the share of urban population increases. Given that urban areas have greater income heterogeneity than rural areas do, urbanization is accompanied by an increase in inequality. At the later stages, when the economy achieves a certain level of economic development, the redistributive policy of the government comes into effect and income inequality moderates. Kuznets' paper has been followed by an array of studies which present mixed evidence. For example, Campano and Salvatore (1988) extend and update the sample to test Kuznets' hypothesis. Their results confirm the existence of the inverted $U$ shaped curve for the top 80 percentile of population. Ram (1988) reexamines Kuznets' hypothesis using a sample of developed and less developed countries. The author finds strong evidence for Kuznets' hypothesis for the whole sample, but little support for the inverted $U$ curve when the sample is limited only to less developed countries. Bahmani-Oskooee et al. (2008) test time series data covering 16 countries for Kuznets' hypothesis. The cointegration analysis only weakly supports the existence of the inverted $U$ relationship between income and inequality.

\section{Finance}

In the presence of credit market imperfections, households, especially the poor ones, encounter obstacles when borrowing for investment and therefore need to rely on personal wealth. We can expect the poor households will underinvest in their human capital and businesses, while the rich households will provide adequate investment. The underinvestment by the poor households will hinder the income convergence between the poor and rich, and, as a result, the income inequality will persist (Galor and Zeira, 1993). The empirical literature generally supports this hypothesis. For example, analyzing Latin American household data, Westley (2001) concludes 
that easing access of smaller enterprises to financial services reduces income inequality. Clarke et al (2006) examine the finance-income inequality relationship employing a sample of 83 countries for the 1960-1995 period. The authors find that financial development reduces income inequality. Barugahara (2012) analyze panel data of 60 countries for the period of 1980-2009. His estimations show that high financial development is associated with low income inequality. $\mathrm{Li}$ and $\mathrm{Yu}(2014)$ examine a sample of 18 Asian countries over the period of 1996-2005. Their results imply that financial reform reduces income inequality. Johansen and Wang (2014) examine data for 60 countries over a period of 1981-2005. The authors conclude that financial repression increases income inequality. Finally, analyzing panel data for 81 countries over the 1985-2010 period, Law et al. (2014) resume that financial development reduces income inequality only after a certain threshold level of institutional quality has been achieved.

\section{Education}

For employers, education usually signals on productivity of employees. As more productive workers are paid more, we can expect that if heads of the poor households have higher and better education, their income will increase. As a result, the gap in income between the poor and rich households and hence inequality will narrow. Generally, the empirical studies support this hypothesis; however, some studies find that either broader access to education increases inequality or the relationship between education and inequality display a non-linear pattern. For example, Hoeller et al. (2014), who analyze data for OECD countries over the period from 1998 to 2009, document that education reduces income inequality. Sylwester (2002), who examines a sample of 50 countries for the years of 1970 and 1990, finds that an increase in expenditure on public education reduces income inequality both in OECD and developing countries albeit the effect is stronger in OECD economies. Analyzing the mathematical model, Hendel et al. (2005) conclude that an increase in access to education through lowering interest rates on study loans actually leads to an increase in inequality. The authors explain this result in the following way. The poor households consist of high ability and low ability members. As a rule, high ability workers receive higher wages than low ability workers. When financial constraints are eased, high ability members take study loans to obtain higher education. After completing their studies, they find well paid jobs and get out of poverty, and after the wage gap between those who leave the pool of the poor households and those who remain there widens, and therefore income inequality rises. Rehme (2006) conclude that more education first increase and then decrease income inequality. The initial increase of inequality documented by 
Rehme (2006) can be explained by Hendel et al.'s (2005) hypothesis, and the subsequent decline in inequality can be due to the redistributive policy which usually becomes effective as the economy graduates from the developing status.

\section{Infrastructure}

Improvements in infrastructure can ameliorate income distribution. Better infrastructure in the rural areas and districts where the poor reside eases access of the low income households to education and health care facilities creating necessary conditions for human capital development. Developed infrastructure also allows poor households to work at jobs which pay more but located at places which previously were difficult to commute to. Furthermore, improved infrastructure gives an opportunity to micro businesses to access more advantageous product and input markets which can increase their income. Calderon and Chong (2004) use a sample of developed and developing countries for the period from 1960 to 1997 to investigate the relationship between infrastructural development and income inequality. The authors conclude that better infrastructure reduces inequality in both developing and developed countries, but the effect is larger in the developed economies. Calderon and Serven (2004), analyzing a sample of more than 100 countries over the period 1960 2000 , also find that infrastructural development lessens income inequality.

\section{Institutions}

Institutions affect allocation and use of public and private resources. If institutions are underdeveloped, resources are misallocated and ineffectively used. The social assistance does not reach the needy, and the poor households refrain from investing their limited wealth because of a high risk of misappropriation. Ultimately, the income inequality prospers. However, the empirical literature presents mixed evidence. Some studies find that better institutions reduce inequality, whereas the other studies find that better institutions increase inequality. For example, GyimahBrempong (2002), who uses panel data for 21 African countries over the period of 1993-1999, finds a positive correlation between corruption and income inequality. Gupta et al. (2002), who employ a sample of countries over the 1980-1997 period, also find a positive relationship between corruption and income inequality. But, Dobson and Ramlogan-Dobson (2010), who employ data for 19 Latin American countries over the period 1984-2003, determine that lower corruption is associated with higher income inequality. As an explanation of this surprising finding, the authors suppose that the improvement of institutions imposes higher transaction costs on the shadow economy where the poor are employed, thereby decreasing their income. 


\section{Empirical approach}

To identify the significant determinants of income inequality, we will estimate the following equation using a two-stage least squares (2SLS) technique which will take into account the possible endogeneity:

income inequality $_{i, t}=\alpha_{0}+\alpha_{1}$ income level $_{i, t}+\alpha_{2}$ finance $_{i, t}+$

$\alpha_{3}$ education $_{i, t}+\alpha_{4}$ infrastructure $_{i, t}+\alpha_{5}$ institutions $_{i, t}+\varepsilon_{i, t}$

where $\varepsilon_{i, t}$ is the error term, $i$ denotes a cross-section dimension of the sample, and $t$ denotes a time series dimension of the sample.

Furthermore, to reexamine the existence of Kuznets' curve, we reestimate equation (1) augmented with the square of income level:

income inequality $_{i, t}=\alpha_{0}+\alpha_{1}$ income level $_{i, t}+\beta_{1}$ income level $_{i, t}^{2}+$

$\alpha_{2}$ finance $_{i, t}+\alpha_{3}$ education $_{i, t}+\alpha_{4}$ infrastructure $_{i, t}+$

$\alpha_{5}$ institutions $_{i, t}+\varepsilon_{i, t}$

\section{Data description}

It is problematic to find an indicator which precisely reflects income inequality; therefore, in empirical analysis, we usually use the proxies of income inequality. Income inequality metrics includes such proxies of inequality as GINI index, Hoover index, Theil index, and ratio of percentiles. In this study, we use GINI index as a proxy for inequality because in contrast to the other proxies, GINI statistics is available for many countries and for a long period. As a proxy of the income determinant, we use GDP per capita. The finance variable is proxied by the real interest rate which is a difference between a nominal lending rate and inflation. To quantify the effect of education on income inequality, we use per capita expenditure on secondary education. Telephone lines per 100 people variable captures the impact of infrastructural development on inequality. We also use the law and order index, which measures the maturity of the legal system and abidance of the laws in a society, to estimate the role of institutions in determining inequality. Since we use 2SLS estimator, additionally, we employ a set of instrumental variables which includes latitude, land-lockedness, legal origin, ethnical fractionalization, religious fractionalization, and lingual fractionalization.

The GINI data were compiled from the databases of World Bank, European Commission, OECD, UN University, and the GINI project. The statistics on the interest rate, inflation, per capita public spending on education, GDP per capita, and telephone lines per 100 people were taken from the database of the World Bank. The 
law and order index data were collected from the PRS Group's reports. The data on latitude and land-lockedness were taken from the database of the CEPII. The figures on ethical, religious, and lingual fractionalization come from Alesina et al (2003). Finally, the legal origin data were taken from La Porta et al (1999).

In our analysis, we use annual data which cover 147 countries and the 19802010 period. The sample includes 33 developed and 114 developing countries. Although the time span is long, we are forced to use the panel data methods because, for many countries, the GINI data are published only periodically. To build the panel, we divide the 1980-2010 period into six sub-periods.

We also have to acknowledge that a change in inequality determinants does not have an immediate effect on income inequality: it takes some time for inequality to respond to a change in the environment. For this reason, we regress the average values of the determinants for the periods of 1981-1985, 1986-1990, 1991-1995, 19962000, 2001-2005, and 2006-2010 on the values of the GINI index for the years of 1985, 1990, 1995, 2000, 2005, and 2010. If the value of the GINI index was missing for the year of interest, we used the value of the nearest year. However, despite all the efforts, the panel is still unbalanced. All monetary variables are in constant 2005 USD. The GINI variable, GDP per capita, and public expenditure on education per capita are expressed in the log form.

\section{Empirical results}

Table 1 reports the estimation results for equation (1) for developed and developing countries. The $\mathrm{p}$-values of $\mathbf{J}$ statistics indicate that the instrumental variables are valid. The regressions also contain a full set of period dummies to control for country trends in income inequality. The negative sign of GDP per capita coefficient implies that an increase in income reduces income inequality in both developed and developing countries, but the effect is not statistically significant at the conventional level. The found negative association is in line with the theory which says that economic development if accompanied by the effective redistributive policy leads to reduction in income inequality. Although this relationship must not be necessary significant in developed countries because these countries have already attained a high level of development, and therefore the further development has only a marginal effect, the impact of economic development on inequality in developing countries is expected to be significant because these countries have a low level of economic development, and therefore a small economic growth should generate a large effect. We can propose two reasons for the insignificant relationship between economic development and inequality in developing countries. First, it can be the case that governments in devel- 
oping countries pursue ineffective redistributive policy which hampers the effect of economic development. Second, the relationship between economic development and income inequality can be non-linear, e.g. follow Kuznets' curve.

Table 1

\section{Determinants of income inequality (dependent variable: $\log$ (Gini index), 2SLS estimator)}

\begin{tabular}{lcc}
\hline \multicolumn{1}{c}{ Variable } & Developed & Developing \\
\hline Log (GDP per capita) & -0.037 & -0.115 \\
Log (Spending on education per capita) & $-0.026^{*}$ & $0.740^{* *}$ \\
Real lending rate & 0.014 & $0.028^{* * *}$ \\
Law and order index & -0.037 & -0.037 \\
Log (phone lines per 100 people) & -0.087 & $-0.480^{* *}$ \\
Constant & $4.269 * * *$ & 1.823 \\
Period dummies & Included & Included \\
N & 137 & 239 \\
J statistics (p-value) & 0.313 & 0.300 \\
\hline
\end{tabular}

Note: $* \mathrm{p}<0.1 ; * * \mathrm{p}<0.05 ; * * * \mathrm{p}<0.01$

An increase in per capita public spending on education significantly decreases income inequality in developed countries but increases income inequality in developing countries. The positive relationship between inequality and public expenditure on education in developing countries is surprising. In fact, an increase in public education spending is supposed to improve access of the low income households to education and therefore reduce income inequality because better educated household members can be eligible for higher paid jobs. To explain this empirical finding, we refer to Hendel et al' (2005) line of argument. Thus, although an increase in public spending on education in developing countries improves access of the poor to education facilities, one part of the poor household members are not able to take advantage of new opportunities due to low ability. As a result, the income gap between those who earn their degree, find well paid employment, and leave the pool of the poor and those who fail to do so increases, and the inequality problem toughens.

Higher real interest rate is associated with greater income inequality in developed as well as developing countries, but the effect is significant only in developing countries. The positive relationship between real interest rate and inequality accords with the empirically confirmed hypothesis that financial development reduces income inequality since high real interest rates impose liquidity constraints on households. The negative 
coefficient of the phone lines per 100 people variable implies that improvement of infrastructure reduces income inequality in advanced and developing economies albeit the effect is statistically significant for the latter. The effect of the improving infrastructure and financial system has a statistically significant effect only in developing countries because the level of infrastructural and financial development in these countries is low; therefore, small improvements in quality of infrastructure and financial institutions immediately produce a large positive effect. In developed countries, in contrast, infrastructure and financial institutions are already well developed, so their improvement has only a marginal effect on income inequality. Finally, development of the legal system negatively but insignificantly affects income inequality in both developing and developed countries. The probable reason why our estimation results show that the effect of institutional development on inequality is insignificant even for developing nations is the relatively short time horizon of the sample. It usually takes a long time for a change in the legal system to generate a marked effect on economy.

Table 2 presents the estimation results of equation (2) which tests for the existence of Kuznets' curve. The results show that although the coefficients of the income variable in level terms are positive and the coefficients of the income variable in quadratic terms are negative in both developed and developing countries, we cannot statistically confirm the existence of Kuznets' curves because all coefficients except the coefficient of the quadratic term for developing countries are statistically insignificant at the conventional levels.

Table 2

\section{Determinants of income inequality: Kuznet's curve (dependent variable: $\log ($ Gini index), 2SLS estimator)}

\begin{tabular}{lcc}
\hline \multicolumn{1}{c}{ Variable } & Developed & Developing \\
\hline Log (GDP per capita) & 3.392 & 2.019 \\
[Log (GDP per capita) $]^{2}$ & -0.166 & $-0.169^{*}$ \\
Log (Spending on education per capita) & $-0.028^{*}$ & $0.818^{* * *}$ \\
Real lending rate & -0.007 & $0.031^{* * *}$ \\
Law and order index & -0.100 & -0.003 \\
Log (phone lines per 100 people) & -0.145 & $-0.368^{*}$ \\
Constant & -12.767 & -5.094 \\
Period dummies & Included & Included \\
$\mathrm{N}$ & 137 & 237 \\
$\mathrm{~J}$ statistics (p-value) & 0.164 & 0.980 \\
\hline
\end{tabular}

Note: $* \mathrm{p}<0.1 ; * * \mathrm{p}<0.05 ; * * * \mathrm{p}<0.01$

For developing countries, this empirical finding implies that economic devel- 
opment will reduce income inequality only after a certain level of development has been achieved. In such a case, it is legitimate to argue that economic development and institutional development are parallel processes, and so when economic development reaches such a threshold level, its institutions become efficient enough to lay grounds for the effective redistributive policy.

\section{Conclusions and policy recommendations}

The empirical analysis of the panel data of 33 developed and 114 developing countries over the 1980-2010 period shows that in developed countries, the statistically significant determinant of income inequality is the public spending on education, while in developing countries, the statistically significant determinants are public spending on education, real lending rate, and the number of phone lines. An increase in public spending on education reduces income inequality in developed countries but raises inequality in developing countries. Real interest rate has a positive association with income inequality in developing countries. Expansion of telecommunications also has a negative effect on income inequality in developing countries. Furthermore, if we compare the magnitudes of the coefficients of the developed countries with those of developing countries, we see that the magnitudes of the latter are the larger. This fact implies that policymakers in developing countries have larger policy space to solve the inequality problem than their colleagues in developed countries.

The results suggest that to reduce income inequality in developed world, policymakers should improve education by increasing public spending on education. Obviously, it is important not only to increase spending but also to take care of the effective use of the resources. The financial resources need to be directed to the areas of education which directly affect labor productivity, e.g. vocational education and research universities. However, we expect that in developing countries, an increase in public spending on education will raise income inequality. Under such conditions, policy makers in developing nations can increase the minimum wages to prevent the wage dispersion and hence an increase in income inequality.

In developing world, to lessen income inequality, policymakers should also raise affordability of credits by moderating lending rates and develop infrastructure. To increase affordability of credits for poor households, policy makers need to implement financial sector reforms which will reduce the interest rate spread and the cost of borrowing of financial resources for credit institutions. Infrastructural development is a broad concept and includes the construction of cultural, sports, and recreational facilities whose existence has a marginal effect on income inequality, so to decrease inequality, the governments of developing countries need to focus on the 
development of infrastructure means which can significantly improve standard of living, such as roads, water supply, electrical grids, and telecommunications. Additionally, policymakers can score a success in combating income inequality by increasing the effectiveness of the redistributive policy. For this purpose, they need to design the policy in the way that will ensure social benefits reach the poor.

\section{End Notes}

1. There is no single comprehensive database on the GINI coefficient covering all countries for a long period; therefore, to compile the dataset for empirical analysis, we used various reliable sources, such as World Bank, OECD, European Commission, UN WIDER, and the Gini project. The reported numbers are averages of the Gini coefficients of all, developed, and developing countries for the corresponding years.

\section{References}

1. Alesina, A., Devleeschauwer, A., Easterly, W., KURLAT, S. \& Wacziarg, R. (2003) Fractionalization. NBER Working Papers 9411, National Bureau of Economic Research.

2. Bahmani-Oskooee, M., Hegerty, S.W. \& Wilmeth, H. (2008) Short-run and longrun determinants of income inequality: evidence from 16 countries. Journal of Post Keynesian Economics 30(3). p. 463-484.

3. Barugahara, F. (2012) Financial development and income inequality: does inflation matter? Applied Economics Quarterly 58(3). p. 193-212.

4. Campano, F. \& Salvatore, D. (1988) Economic development, income inequality and Kuznets' U-shaped hypothesis. Journal of Policy Modeling 10(2). p.265-280.

5. Calderón, C. \& Chong, A. (2004) Volume and quality of infrastructure and the distribution of income: an empirical investigation. Review of Income and Wealth 50(1). p. 87-106.

6. Calderon, C. \& Serven, L. (2004) The effects of infrastructure development on growth and income distribution. Policy Research Working Paper Series 3400, The World Bank.

7. Clarke, G.R.G., Xu, L.C. \& Zou, H. (2006) Finance and income inequality: What Do the Data Tell Us? Southern Economic Journal 72(3). p. 578-596.

8. Dobson, S. \& Ramlogan-Dobson, C. (2010) Is there a trade-off between income inequality and corruption? Evidence from Latin America. Economics Letters 107(2). p. 102-104.

9. Galor, O. \& Zeira, J. (1993) Income distribution and macroeconomics. Review of 
Economic Studies 60(1). p. 35-52.

10. Gupta, S., Davoodi, H. \& Alonso-Terme, R. (2002) Does corruption affect income inequality and poverty? Economics of Governance 3(1). p. 23-45.

11. Gyimah-Brempong, K. (2002) Corruption, economic growth, and income inequality in Africa. Economics of Governance 3(3). p. 183-209.

12. Hendel, I., Shapiro, J. \& Willen, P. (2005) Educational opportunity and income inequality. Journal of Public Economics 89(5-6). p. 841-870.

13. Hoeller, P., Joumard, I. \& Koske, I. (2014) Reducing income inequality while boosting economic growth: can it be done? Evidence from OECD countries. The Singapore Economic Review 59(1). p.1450001-1-1.

14. Johansson, A.C. \& Wang, X. (2014) Financial sector policies and income inequality. China Economic Review 31(C). p. 367-378.

15. Kuznets, S. (1955) Economic growth and income inequality. The American Economic Review 45(1). p. 1-28.

16. La Porta, R., Lopez-de-Silanes, F., Shleifer, A. \& Vishny, R. (1999) The Quality of Government. Journal of Law, Economics and Organization 15(1), p.222-79.

17. Law, S.H., Tan, H.B. \& Azman-Saini, W.N.W. (2014) Financial development and income inequality at different levels of institutional quality. Emerging Markets Finance and Trade 50(1S). p.21-33.

18. Li, J. \& Yu, H. (2014) Income inequality and financial reform in Asia: the role of human capital. Applied Economics 46(24). p. 2920-2935.

19. Ram, R. (1988) Economic development and income inequality: further evidence on the U-curve hypothesis. World Development 16(11). p. 1371-1376.

20. Rehme, G. (2007) Education, Economic Growth and Measured Income Inequality. Economica 74(295). p. 493-514.

21. Sylwester, K. (2002) Can education expenditures reduce income inequality? Economics of Education Review 21(1). p. 43-52.

22. Westley, G.D. (2001) Can financial market policies reduce income inequality? Technical Papers Series MSM-112, the Inter-American Development Bank. 